\title{
The Model of the Virtual Relations Infrastructure of Socioeconomic Systems and Information Technologies of the Regional Agro-industrial Complex*
}

\author{
Vladimir Novikov \\ Department of State and Municipal Administration \\ Kuban State Technological University \\ Krasnodar, Russia \\ E-mail: vs.novikov@mail.ru
}

Rustem Shichiyakh

Department of Management

Kuban State Agrarian University

Krasnodar, Russia

E-mail: s.r.a.01@mail.ru

\author{
Elena Klochko \\ Department of Management \\ Kuban State Agrarian University \\ Krasnodar, Russia \\ E-mail: magadan.79@mail.ru \\ Julia Galitskaya \\ Department of Accounting, Analysis and Audit \\ Kuban State Technological University \\ Krasnodar, Russia \\ E-mail: riban1@mail.ru
}

\begin{abstract}
The virtual form of operation in socio-economic systems of the agro-industrial complex is becoming a promising trend in the Russian economy. Virtualization of socio-economic systems in the agro-industrial sector necessitates studying the infrastructure and tools of this business organization form. By the analogy to the real world, virtual socio-economic systems have certain legal capacity (transactions, settlement accounts, etc.). The Internet is becoming a sphere to pursue business interests of all agroindustrial socio-economic systems, which results not only in multiple opportunities, but also in numerous problems, ranging from supplementary costs for technology to completely new control methods. The scientific novelty of the present study is in developing a theoretical model of the virtual relations infrastructure of socio-economic systems in the regional agro-industrial complex, with the account taken of information technology development in a globalized economy. As described in the research, the virtual relations infrastructure of the regional agro-industrial complex is characterized by three parameters: the specificity of constitutive elements of the infrastructure, their number and structure, i.e. the type of relations between the constituent elements. The article substantiates the factors impeding the development of virtual relations between agro-industrial complex subjects and presents the author's conceptual model of the virtual relations infrastructure of socio-economic systems of the regional agro-industrial complex.
\end{abstract}

Keywords-integration; subjects of management; objects of management; infrastructure model; virtual economy; agroindustrial complex

*Fund: The study was carried out with financial support from the Russian Foundation for Basic Research in the framework of the scientific project No. 18-310-00062.

\section{INTRODUCTION}

The integration of socio-economic systems of the virtual relations infrastructure is understood to mean the implemented continuous one-to-one entrepreneurial interaction, with its reverse action also being continuous. The one-to-oneness, continuity and existing reverse functions provide legal identification of integration elements, processes and their arbitration. It can be confidently said that Visa and MasterCard payment gateways, Internet-trading systems, etc. are the analogues of such systems. Today, there is practically no research on virtual integration of socioeconomic systems of the agro-industrial complex. Thus, we consider it relevant to study the processes of virtualization of economic actors and infrastructure elements of the regional agro-industrial complex.

Integration of socio-economic systems of the agroindustrial complex into the virtual relations infrastructure of the region consists of units, self-grouped according to the types of connections related to resource and information needs. Units of such a system can create interest groups, virtual distribution networks and other digital units of business relations. Each unit represents a horizontal structure system, which provides an opportunity to independently structure economic processes in a non-hierarchical (nonrigid), weakly bound environment. "Economic unit" system consists of information resources (they define its visual representation in the information space), status and connection control cells. The unit is a neuron that functions when integrating the subjects of the virtual relations infrastructure in the regional economy, and directly 
influences the changing structure, shaping its informational and virtual landscape.

Developing innovations in the Russian economy, in ecommerce in particular, fully corresponds to global trends. In this regard, Russian researchers pay increasing attention to the issues of creating the virtual relations infrastructure of socio-economic systems in the agro-industrial sector, based on the development of information technologies in a globalized economy. It should be mentioned that the integration of socio-economic systems of the virtual relations infrastructure in the regional economy is interconnected with the real business system and provides it with structured information on facts (events) and their observational generalization in terms of place, time, activity and circumstances.

In their works, Kim B., Barua A., Whinston A. studied the questions of virtual economics and digitalization of economic processes [5]. It should be emphasized that researches Dawson M., Foster J. understand virtual economic processes as a form of capitalism [2]. Tompson W. explores Russian economic processes from the viewpoint of virtuality of subjects and objects [8].

In their study, Yarushkina E., Zhukov B., Dianova V. propose new categories, interpretations of the virtual relationship system and associated constructs of the educational system, which serves a source of innovation and provides new educational programs to improve the quality of human capital [6]. Some issues of virtual integration and its influence on state leaders' activity were examined in the research by Bernauer T., Achini Ch. [1], Filos E., Ouzounis V. [4].

Completely new concepts and categories related to virtual economy have been developed by Epifanova T., Shatkovskaya T., Romanenko N., Mosienko T., Tkachenko M. [3]. The issues of cryptocurrency have been tackled by Penkova I., Korolev V., Butenko E., Glazkova I., Eldarov S. in the corresponding research [7].

The working hypothesis of the research is based on the authors' assumption that increasing the innovation level and the convenience of implementing objectives in the virtual space can only be achieved through developing the model of the virtual relations infrastructure of socio-economic systems in the regional agro-industrial complex.

\section{METHODS}

The virtual relations infrastructure of the regional economy provides the necessary conditions for socioeconomic activities and facilitates their coordination at all levels of production hierarchy: international, macro and meso (regional) levels of the country, at the levels of industries and enterprises [11].

The major objective of the virtual relations infrastructure in the regional economy is to ensure the connections between socio-economic systems and create organizational and economic preconditions for integrating the systems into a single organism aimed at effective regional economy operation.

The theoretical background of the research is represented by modern scientific concepts of economic theory, management theory, fundamental works by Russian and foreign scientists on managing new organizational forms based on the introduction of Internet technologies.

When substantiating theoretical propositions and conclusions, the authors applied the following general scientific methods: system and integrated approaches, comparative analysis, scientific abstraction, analysis and synthesis, etc. The work synthesizes the results of Russian and foreign scientific research, conference and seminar materials and Internet publications.

\section{RESULTS}

In the functioning of the subjects of virtual interaction at the level of the regional agro-industrial complex, there are apparent constraints that impede network collaboration. Among them are the following:

- existing financial, economic, and organizational market constraints, which substantiates the need for virtual network coordinators to control authorities and monitor results;

- implementing virtual connections of socio-economic systems of the regional agro-industrial complex loses its significance in case of no visible financial result and motivation;

- uneven telecommunications coverage of certain regions requires additional financial resources for providing technologically synchronized virtual network of the agro-industrial complex;

- language barrier, which leads to difficulties in communication and establishing long-term contacts, conflicts of interest, intense competition between socio-economic systems within the region and between other regions of the Russian Federation.

When studying the process of integrating virtual entrepreneurship into the regional economic space (in cooperation with Metelskaya E.A.), alongside with positive trends, we identified significant constraints for integration development of the subjects of the virtual relations infrastructure in the regional economy [9]. We should highlight two large problem groups: economic and social, including: regulatory and legislative issues; insufficient development of the organizational and technological platform for the virtual infrastructure of regional agroindustry; insufficient distribution of communications and network technologies in Russian regions; insufficient development of information and virtual technologies in the agro-industrial sector; underfunding of research and development in the field of virtual entrepreneurship infrastructure development in the agro-industrial sector; lack of professionals in the field of information, information security and agro-industrial entrepreneurship; lack of business confidence in virtual infrastructure entrepreneurship 
economy, which we classify into groups: international constraints, national constraints, regional constraints, human factor constraints.

Additionally, the two approaches to implementing the virtual relations infrastructure of socio-economic systems in the region proposed by Romanchevskiy B.V. deserve closer consideration [10].

The first approach is to adopt the experience of other, mainly European, countries. The speed of development under this approach is ensured by allocated funds (not less than $5-7 \%$ of GDP). What is more, this approach requires a major change in the Russian mentality and refocusing public consciousness on goals, priorities and development trends characteristic of the American or European way of life.

"Fig. 1" presents the constraints for the integration of the virtual relations infrastructure subjects in the regional

\begin{tabular}{|c|c|c|c|}
\hline \multicolumn{4}{|c|}{ Constraints for virtual integration of socio-economic systems in the regional agro-industrial complex } \\
\hline \multicolumn{4}{|c|}{$\dot{t}$} \\
\hline $\begin{array}{c}\text { International } \\
\text { constrains }\end{array}$ & $\begin{array}{c}\text { National } \\
\text { constraints }\end{array}$ & $\begin{array}{l}\text { Regional } \\
\text { constraints }\end{array}$ & "Human factor" cons \\
\hline $\begin{array}{l}\text { market instability; } \\
\text { legislative activity of } \\
\text { countries, business } \\
\text { alliances, international } \\
\text { organizations (the } \\
\text { United Nations, } \\
\text { BRICS), etc.); geopoli- } \\
\text { tics }\end{array}$ & \multicolumn{2}{|c|}{$\begin{array}{l}\text { cultural incompatibility of partner compa- } \\
\text { nies' personnel; people in some territories } \\
\text { being not ready for the changes introduced in } \\
\text { other territories; excessive economic reliance } \\
\text { on classical factors of production }\end{array}$} & $\begin{array}{l}\text { cultural incompatibility of } \\
\text { nies' personnel; people in } \\
\text { being not ready for the ch } \\
\text { in other territories; excess } \\
\text { reliance on classical factor } \\
\text { risks of virtual infrastruct } \\
\text { of negative influence of hy }\end{array}$ \\
\hline
\end{tabular}

Fig. 1. Constraints for developing integration relations in the regional agro-industrial complex.

The second approach implies choosing a way to correspond to Russian criteria and characteristics of life quality, socio-cultural peculiarities and under today's socioeconomic conditions demands minimal capital investment from the state. However, this approach requires at least minimum economic growth, political stability and political will of the executive and legislative authorities, who introduce the high priority task of transition to the information society.

The authors' theoretical model of the virtual relations infrastructure of socio-economic systems at the regional level is presented in "Fig. 2".

Under this model, the types of socio-economic systems at the regional level can be characterized as follows:

- Short-term modular network, uniting partners with a clear focus on key competencies. Such a network is characterized by low partner replaceability, limited lifetime, asymmetric dependence of network partners;

- The network for fulfilling special orders is aimed at mobilizing high-quality project-oriented resources. Partner replaceability is available, timing of orders is strictly limited, and the dependence of network partners is symmetric;
- Network integration in a certain field is focused on making coordinated decisions and optimizing customer services. Such networks are characterized by a high degree of openness and symmetric dependence of partners; cooperation is aimed at working out coordinated solutions;

- Controlled networks, where one company manages production processes of a globally operating network with unilaterally replaceable partners;

- Long-term network pools are targeted to receiving regular orders of various kind. Cooperation is based on confidence in partners and shared values. They are characterized by symmetric dependence of network partners and are of great concern to small and medium-sized enterprises, which due to this cooperation, get an opportunity to obtain orders and reduce costs;

- Large scope project networks are created by organizations aimed at efficient resource pooling to carry out large scale (long-term) projects;

- Special virtual networks focused on implementing certain orders with digital data transmission. Global computing and communication networks are commonly used to organize and coordinate virtual enterprises of this type. 
commitments relations with the centre and other agents (see "Fig. 2"). Sustainable relations arise only for the time of order fulfilment or when the socio-economic system of the agro-industrial sector has to perform certain commitments. Orders can be different, spontaneous and unevenly distributed over time.

As a rule, socio-economic systems of the virtual relations infrastructure do not have permanent, backed by

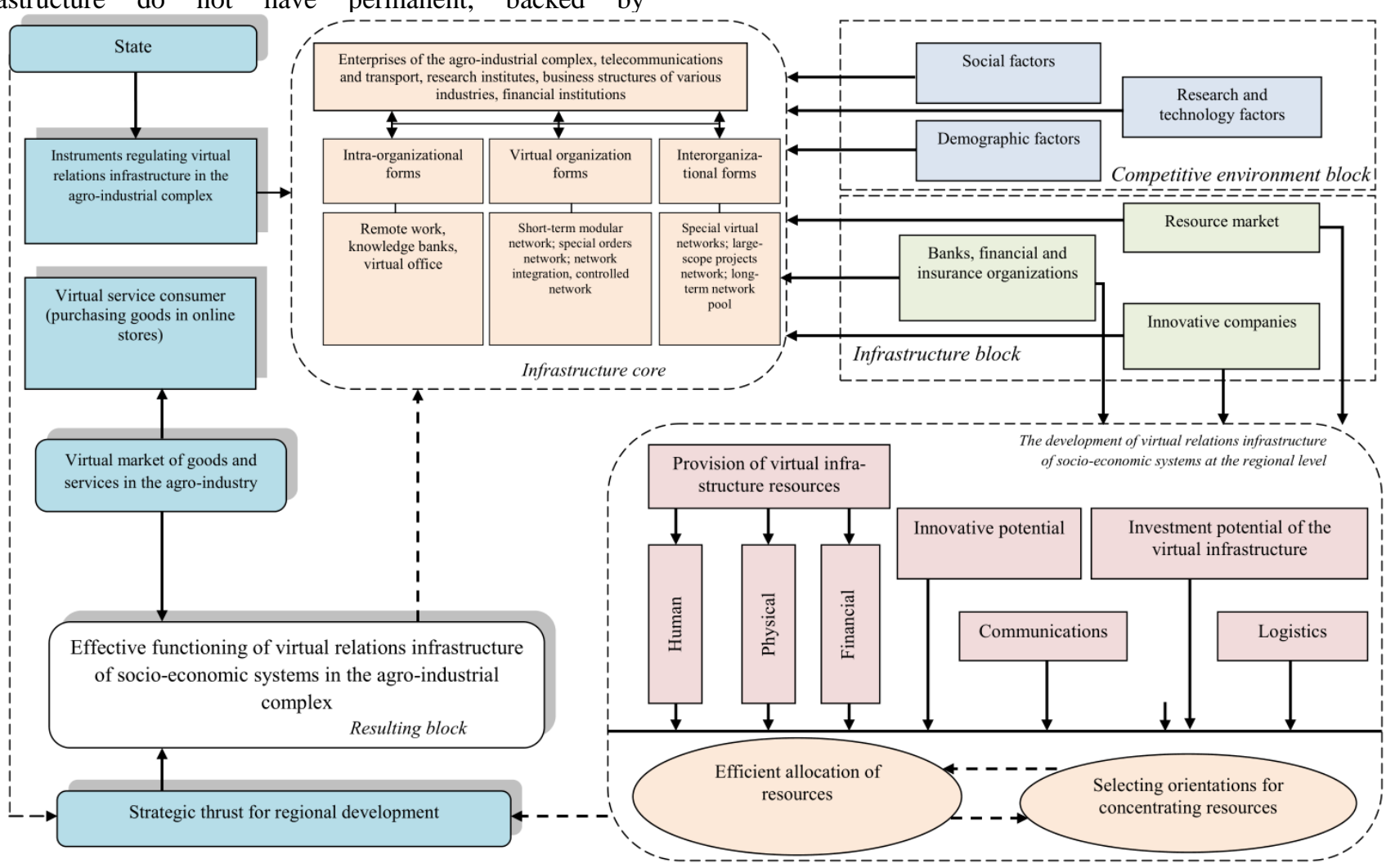

Fig. 2. The model of the virtual relations infrastructure of socio-economic systems in the regional agro-industrial complex.

Under such conditions, it is of primary importance to form the core of the virtual relations infrastructure of socioeconomic systems in the regional agro-industrial complex. The core is understood as a group of participants having the necessary competencies (resources, knowledge and skills) for searching and fulfilling market orders and performing tasks in accordance with the purpose and activity of the socio-economic system. The core based on the existing dynamic network is to be formed as follows:

- Defining market opportunities, developing a business idea as an area of the socio-economic system activity;

- Defining minimum key competencies to perform in the area of the socio-economic system activity;

- Defining the participants of a dynamic network, their capabilities and competencies;

- Creating matrices of network participants' capabilities in accordance with the required core competencies for operation of the socio-economic system.

\section{DISCUSSION}

Over the past 7-10 years, in the Russian Federation there emerged the factors of socio-economic, scientific, technical and cultural development, which can be considered the preconditions for the transition to the high-quality virtual relations infrastructure of socio-economic systems in the regional agro-industrial complex. This fact confirms the results obtained in the presented study; the preconditions include the following:

- information becomes a public development resource, its use is compatible with the use of traditional resources (energy, raw materials, etc.);

- the market of telecommunications, information technologies, products and services has been established and is successfully developing in the Russian Federation;

- political and economic reasons for the transition to the information society are becoming more relevant in public opinion; 
[7] Penkova I., Korolev V. Crypto currencies as a modern financial too of digital economy: global experience of state regulation // Advances in Intelligent Systems and Computing. 2019. No. 726. Pp. 326-334.

- being connecting to the rest of the world via communication channels, the Russian Federation is part of the today's global political and economic community;

- the government structure responsible for providing the information technology background for transition has been formed and is functioning.

The federal target program "Digital Russia" was launched in 2002 and completed in 2010. In October 2010, the Government of the Russian Federation approved the "Information Society (2011-2020)" state program; federal budget expenditures on the program are estimated at 123.1 billion roubles annually. According to the developers of the program, its successful implementation will allow the Russian Federation to enter the top ten countries in the world by information technologies development index and the top twenty countries by e-government and network society development, by 2020 .

\section{CONCLUSION}

The research has identified a number of important issues:

First, there are certain constraints in the functioning of virtual infrastructure subjects at the level of the regional agro-industrial complex, which deter network collaboration.

Second, in the study, the constraints for the integration of the virtual relations infrastructure subjects in the regional economy are classified into groups: international constraints, national constraints, regional constraints, human factor constraints.

Third, the types of socio-economic systems of the regional agro-industrial complex have been characterized.

Fourth, the model of the virtual relations infrastructure of socio-economic systems in the regional agro-industrial complex has been developed.

\section{REFERENCES}

[1] Bernauer T., Achini Ch. From "real" to "virtual" states? // Integration of the world economy and its effects on government activity. European Journal of International Relations, 2000. No. 2. Pp. 223-276.

[2] Dawson M., Foster J. Virtual capitalism: the political economy of the information highway // Monthly Review. 1996. No. 3(48). Pp. 40-58.

[3] Epifanova T., Shatkovskaya T. Legal provision of clustering in Russia as environment for development of innovations // International Journal of Trade and Global Markets. 2017. No. 2-3(10). Pp. 217-225.

[4] Filos E., Ouzounis V. Virtual organizations: technologies, trends, standards and the contribution of the European R\&D programs // International Journal of Computer Applications in Technology. 2003. No. 1-4(18). Pp. 6.

[5] Kim B., Barua A., Whinston A.B. Virtual field experiments for a digital economy: a new research methodology for exploring an information economy // Decision Support Systems. 2002. No. 3(32). Pp. 215-231.

[6] Novikov V., Klochko E. On peculiarities of the virtual economy of modern Russia: category, virtual relationships, educational constructs // Mediterranean Journal of Social Sciences. 2015. No. 36(6). Pp. 247-256.
[8] Tompson W. The price of everything and the value of nothing? unravelling the workings of Russia "virtual economy" // Economy and Society. 1999. No. 2(28). Pp. 256-280.

[9] Metelskaya E.A., Novikov V.S. Restricted integration of the subjects of virtual entrepreneurship infrastructure in the region's economy // Economics and Entrepreneurship. 2014. No. 11-2. Pp. 814-819.

[10] Romanchevsk B.V. Innovative development of virtual management under the transition to the information society, $\mathrm{PhD}$ thesis, Institute of International Law and Economics, Moscow. 2013. 186 p.

[11] Chernenko G.A. Production infrastructure of the region // Vestnik universiteta (State University of Management). 2008. No. 13 (23). Pp. 34-39. 